\title{
Impacts of tropical cyclones on hydrochemistry of a subtropical forest
}

\author{
C. T. Chang ${ }^{1}$, S. P. Hamburg ${ }^{2}$, J. L. Hwong ${ }^{3}$, N. H. Lin ${ }^{4}$, M. L. Hsueh ${ }^{5}$, M. C. Chen ${ }^{6}$, and T. C. Lin ${ }^{7}$ \\ ${ }^{1}$ Department of Geography, National Taiwan University, Taipei 10617, Taiwan \\ ${ }^{2}$ Environmental Defense Fund, 257 Park Avenue South, New York, NY 10010, USA \\ ${ }^{3}$ Taiwan Forestry Research Institute, Taipei 10066, Taiwan \\ ${ }^{4}$ Department of Atmospheric Sciences, National Central University, Chung-Li 32001, Taiwan \\ ${ }^{5}$ Taiwan Endemic Species Research Institute, Nantou 55244, Taiwan \\ ${ }^{6}$ School of Forestry and Resource Conservation, National Taiwan University, Taipei 10617, Taiwan \\ ${ }^{7}$ Department of Life Science, National Taiwan Normal University, Taipei 11677, Taiwan
}

Correspondence to: T. C. Lin (tclin@ntnu.edu.tw)

Received: 23 March 2013 - Published in Hydrol. Earth Syst. Sci. Discuss.: 10 April 2013

Revised: 5 July 2013 - Accepted: 24 August 2013 - Published: 7 October 2013

\begin{abstract}
Tropical cyclones (typhoons/hurricanes) have major impacts on the biogeochemistry of forest ecosystems, but the stochastic nature and the long intervals between storms means that there are limited data on their effects. We characterised the impacts of 14 typhoons over six years on hydrochemistry of a subtropical forest plantation in Taiwan, a region experiencing frequent typhoons. Typhoons contributed $1 / 3$ of the annual rainfall on average, but ranged from 4 to $55 \%$. The stochastic nature of annual typhoon related precipitation poses a challenge with respect to managing the impacts of these extreme events. This challenge is exacerbated by the fact that typhoon-related rainfall is not significantly correlated with wind velocity, the current focus of weather forecasts. Thus, little advance warning is provided for the hydrological impacts of these storms.

The typhoons we studied contributed approximately one third of the annual input and output of most nutrients (except nitrogen) during an average 9.5 day $\mathrm{yr}^{-1}$ period, resulting in nutrient input/output rates an order of magnitude greater than during non-typhoon months. Nitrate output balanced input during the non-typhoon period, but during the typhoon period an average of $10 \mathrm{~kg} \mathrm{ha}^{-1} \mathrm{yr}^{-1}$ nitrate was lost. Streamwater chemistry exhibited similarly high variability during typhoon and non-typhoon periods and returned to pretyphoon levels one to three weeks following each typhoon. The streamwater chemistry appears to be very resilient in response to typhoons, resulting in minimal loss of nutrients.
\end{abstract}

\section{Introduction}

Tropical cyclones (hurricanes and typhoons) are known to have major and even catastrophic effects on ecosystem structure and function. Although some have suggested that inclusion of rainfall into to the classification of storm intensity would be useful (Scatena and Larsen, 1991), historically tropical cyclones have been classified exclusively by barometric pressure and wind velocity at the centre of the cyclone. The Saffir-Simpson Hurricane Scale uses the speed of sustained winds to classify hurricanes into five intensity categories and is the most commonly used predictor of potential damage and flooding resulting from hurricanes (Simpson and Riehl, 1981; NWS, 2009). It is assumed that tropical cyclones with higher winds have greater potential to cause damage (Bell et al., 2000; Powell and Reinhold, 2007).

Forest ecosystem damage caused by uprooting, bolesnapping, and defoliation has been shown to be directly related to wind velocity (Everham III and Brokaw, 1996; Cook and Goyens, 2008). Yet, at wind-speeds below site and tree species specific thresholds, damages can be minimal (Lin et al., 2003; Ancelin et al., 2004). In a study of wind-induced failure of Sitka spruce, velocities $>30 \mathrm{~m} \mathrm{~s}^{-1}$ caused stem breakage in un-thinned $52 \mathrm{yr}$ old stands (Moore and Quine, 2000). In a subtropical rainforest in northeastern Taiwan, typhoons with maximum wind velocities $>51 \mathrm{~m} \mathrm{~s}^{-1}$ accounted for $83 \%$ of the inter-annual variation in litterfall 
and those with lower wind speeds accounted for none of the observed variability using a regression model (Lin et al., 2003).

In spite of the wind-induced damage associated with tropical cyclones, heavy rains associated with cyclones often have greater impacts on human and natural systems. For example, the 56 deaths and up to $\$ 6$ billion in property damage caused by the 1999 category 2 hurricane Floyd in the US was due to extensive flooding (Atallah and Bosart, 2003). The more than 400 deaths caused by the 2009 typhoon Morakot in southern Taiwan was a result of landslides and debris flows induced by the nearly $3000 \mathrm{~mm}$ of precipitation over three days (Lin, C. W. et al., 2011; Tsou et al., 2011). Forest systems also show a strong relationship between the severity of storm induced damage and rainfall quantity (Scatena and Larsen, 1991; West et al., 2011). Saturated soils resulting from high amounts of rainfall have been suggested as a major cause of increased tree mortality during hurricane disturbances in Virginia, North Carolina, northeastern United States and Australia (Trousdell et al., 1965; Cremer et al., 1977; Foster, 1988). Although landslides, extensive tree falls, and debris flows can be catastrophic when they occur, such disasters are localized in impact compared to the much larger area experiencing heavy rainfall during a tropical cyclone event. Even if the heavy rainfall does not cause catastrophic damages, it might cause major shifts in regional hydrology and biogeochemistry. Dramatic shifts in streamwater chemistry during and following tropical cyclones have been observed in Puerto Rico and Taiwan (Wang et al., 1998; Schaefer et al., 2000; Tsai et al., 2009). The annual export of $\mathrm{K}^{+}, \mathrm{NO}_{3}{ }^{-}$and $\mathrm{NH}_{4}{ }^{+}$in the year following hurricane Hugo (1989) increased more than $100 \%$ and the effect was greater than that caused by canopy gaps and selective cutting (Schaefer et al., 2000; McDowell, 2001; Beard et al., 2005). Despite the potential impacts that cyclone-induced rains might have on ecosystem biogeochemistry, few studies have explored these impacts.

The fact that human-induced global climate change is projected to increase climate extremes, e.g. drought (Dail, 2011), flooding (Christensen and Christensen, 2003), heat weaves (Beniston and Diaz, 2004) and the intensity of tropical cyclones (Webster et al., 2005), is of growing concern. The lack of empirical data on the effects of tropical cyclones on hydrology and nutrient cycling limits our understanding of the potential effects of climate change on ecosystem structure and function.

Understanding the effects of tropical cyclones on ecosystem biogeochemistry and hydrology requires having a good understanding of streamwater patterns, which in turn requires long-term data. Yet, the unpredictability, in space and time, of tropical cyclones has resulted in a limited amount of empirical data on the effects of tropical cyclones on ecosystem hydrochemistry. Without confidence that tropical cyclones will impact a site on a regular basis, it is difficult to justify the effort required to collect long-term data, except at maybe a few sites, in the hope that a tropical cyclone will impact the site.

Given that differences in site and cyclone characteristics affect the comparability of ecosystem responses among sites, it is difficult to assemble a large enough dataset capable of providing useful models of the impacts of typhoons/hurricanes on hydrochemical and physiological processes (Everham III and Brokaw, 1996; Hornbeck et al., 1997; Lin et al., 2003; Likens and Buso, 2006; Feller, 2010). Further compounding this challenge is the fact that, data from a single or even a couple of tropical cyclones at a single site may not capture the full range of ecosystem responses and elucidate the underlying mechanisms, even at that site. Currently, much of our understanding of the effects of tropical cyclones on ecosystem biogeochemistry comes from studies of a few tropical cyclones, e.g. 1989 hurricane Hugo in central America (Schaefer et al., 2000; Heartsill-Scalley et al., 2007), 1938 hurricane in northeast USA (Foster et al., 1997; Aber et al., 2002), 2005 hurricane Katrina in southeast USA (Chambers et al., 2007; Shiller et al., 2012), 2006 tropical cyclones Monica and Larry in Australia (Gleason et al., 2008; Wallace et al., 2009). Examining cyclone-ecosystem interactions with data from numerous tropical cyclones impacting the same site has the potential to provide a critical and comprehensive window on ecosystem impacts that is currently lacking. Taiwan, $36000 \mathrm{~km}^{2}$, is an ideal location to study the effects of typical cyclones on forest ecosystems as there are, on average, three to six typhoons making landfall annually (Lin, T. C. et al., 2011). Every year a large proportion of Taiwan experiences heavy rainfall caused by typhoons, thus most forests on the island experience the influence of typhoons on a regular basis. Several studies have examined the hydrochemical responses to typhoon disturbance in Taiwan, but most report the influences of only a single typhoon (Wang et al., 1998, 1999; Tsai et al., 2009).

Here we present a study on the effects of 14 typhoons on hydrochemical cycling in a first-order gaged forested watershed between 2005 and 2010, the largest such study of its kind. Our objectives were to (1) quantify the influence of typhoons on water and nutrient input and output budgets, and (2) characterise the effects of typhoons on temporal variation of streamwater chemistry and its post-typhoon recovery.

\section{Material and methods}

\subsection{Study site}

The study was conducted at Watershed \#4 (W4, 5.9 ha) of the 460 ha Lienhuachi Experimental Forest $\left(120^{\circ} 54^{\prime} \mathrm{E}\right.$, $23^{\circ} 54^{\prime} \mathrm{N}$ ) in central Taiwan (Fig. 1). Two hundred and sixty ha of the Experimental Forest are natural hardwood forests, the only such remaining forests in the central Taiwan's lowlands (Hwong et al., 2002), dominated by Fagaceae and Lauraceae tree species. The vegetation on the remaining 


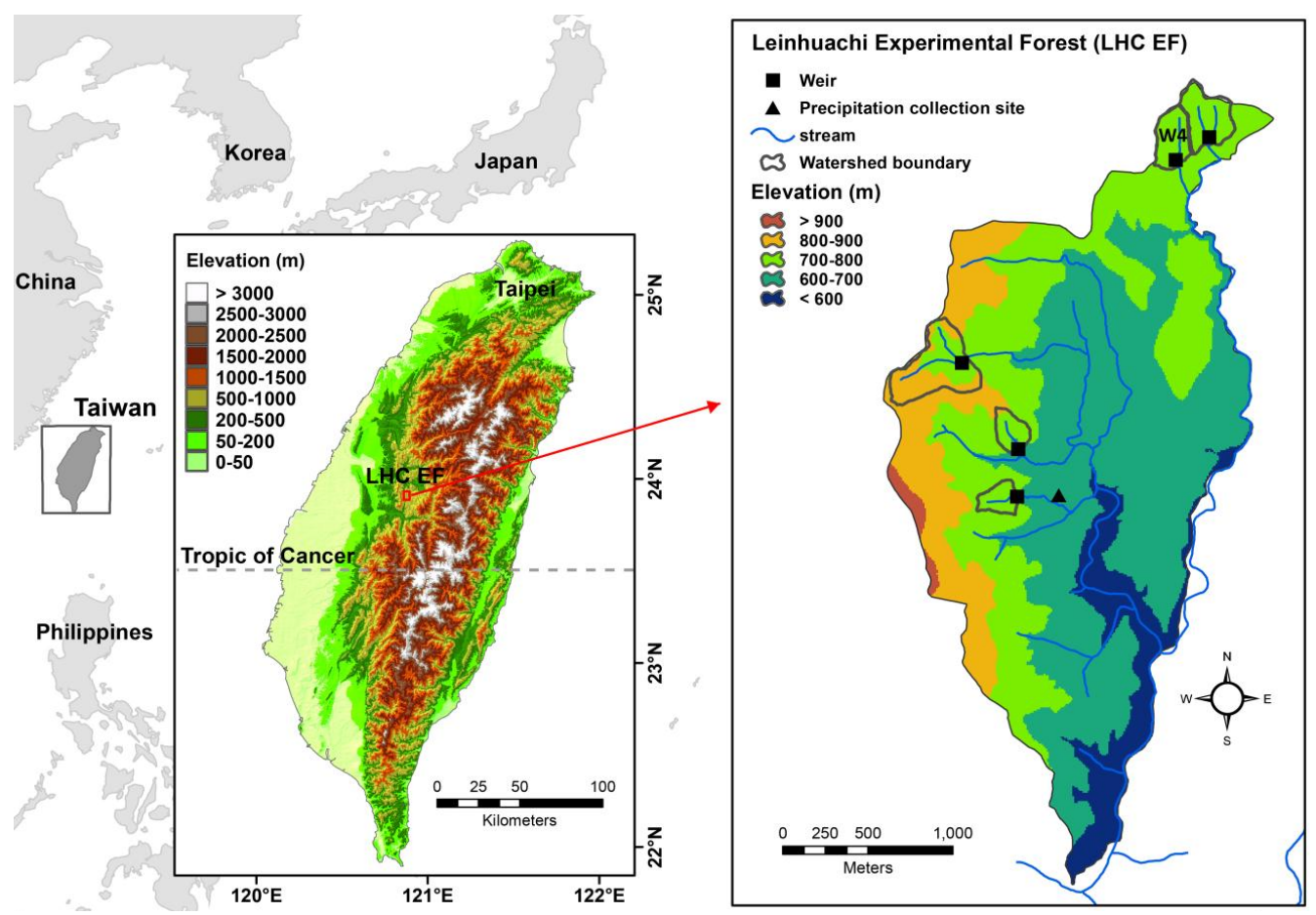

Fig. 1. Location map of study site - Leinhuachi Experimental forest of central Taiwan.

200 ha of the Experimental Forest are primarily conifer plantations (Hwong et al., 2002). The mean annual precipitation is $2200 \mathrm{~mm}$, and mean annual temperature is $20.8^{\circ} \mathrm{C}$, lowest in January at $14.9^{\circ} \mathrm{C}$ and highest in July at $25.4{ }^{\circ} \mathrm{C}(1961$ to 1998 averages; Lu et al., 2000). There is a distinctive dry season between October and February with mean precipitation of $230 \mathrm{~mm}$ or approximately $10 \%$ of the annual precipitation (Lu et al., 2000).

Prior to 1978, the entire Lienhuachi Experimental Forest could be characterised as natural evergreen hardwood forest, with anthropogenic disturbances limited to small-scale selective logging and bamboo plantations. W4 was clear-cut from November 1978 to March 1979 using skyline logging (Koh et al., 1978) after which the natural regeneration was periodically cut until 1981 when it was planted with Cunninghamia lanceolata. C. lanceolata is a native conifer widely grown in low elevations of southeastern China and Taiwan. The planting was carried out using standard protocols for the period, herbaceous plants and shrubs were removed followed by mechanical site preparation (leveling and litter removal), and one-year old $30 \mathrm{~cm}$ seedlings were planted at 2400 trees ha $^{-1}$ using $2 \mathrm{~m} \times 2 \mathrm{~m}$ spacing. Between 1982 and 1985 weeds were cut several times a year and new seedlings planted to replace those that died. In 1986 suppressed, damaged or poor-growth trees were cut, resulting in a density of 1000-1200 trees ha ${ }^{-1}$. There has been no management of the watershed since 1986 .

In 1967 a $90^{\circ}$ V-notch weir was constructed directly on top of the sandstone and shale bedrock. The water- shed is assumed to be watertight based on the small difference between streamflow measurements at the weir (19711975), $1190 \mathrm{~mm} \mathrm{yr}^{-1}$ and streamflow derived from subtracting calculated evapotranspiration, from rainfall (1961-1996), $1020 \mathrm{~mm} \mathrm{yr}^{-1}$ (Hwong et al., 2002). Stilling pond water levels were recorded using a Submersible Pressure Transmitter (PS98i Instrumentation Northwest, Kirland, WA) and flow rates calculated from an empirically validated stagedischarge curve (Hsiao et al., 2007). There is year around streamflow, but the frequent heavy storms, particularly typhoons, cause data gaps due to sediment filling the stilling pond. During the six-year study period (2005-2010) we have complete streamflow data for 2008 and 2009.

\subsection{Methods}

The Central Weather Bureau of Taiwan issued warnings for a total of 35 typhoons between 2005 and 2010. Even when the path of a typhoon was distant from Lienhuachi Experimental Forest, the storm's air mass often brought additional rainfall. We considered precipitation typhoon-related if there was $>50 \mathrm{~mm}$ of precipitation during the period between the first and last warnings for a specific typhoon issued by the Central Weather Bureau of Taiwan. Because changes in streamflow lag rainfall in W4 by only a couple hours we also defined typhoon-induced stream flow as the flow occurring between the first and last warnings. For example, typhoon Norris (1980) brought $390 \mathrm{~mm}$ of rainfall and streamflow returned to pre-typhoon rates five hours after the rain 
stopped (Liaw et al., 1998). Similarly, typhoon Talim (2005) brought $140 \mathrm{~mm}$ of rainfall and streamflow returned to the low pre-storm levels just five hours after the rain stopped (Tsai et al., 2009). Precipitation resulting from southwesterly airflows associated with typhoons that had already passed Taiwan was not included in our study, as these winds led to heavy storm warnings not typhoon warnings. Thus, typhooninduced rainfall and streamflow reported in our study are minimum estimates.

Between 2005 and 2010 weekly precipitation samples were collected $2 \mathrm{~km}$ from the watershed using a wetonly collector (Modified Anderson wet-dry collector with a polypropylene bucket - diameter $29.7 \mathrm{~cm}$, height $26.8 \mathrm{~cm}-$ a metal lid covers the bucket when it is not raining). Weekly streamwater samples were collected manually above the stilling pond in the natural stream immediately following collection of precipitation samples. We did not collect precipitation samples in November and December, 2006 and there were no stream water samples collected between October 2006 and February 2007 (there were no typhoons during this period). All water samples were collected in $250 \mathrm{~mL}$, acid-washed, polyethylene bottles, and immediately stored at $4{ }^{\circ} \mathrm{C}$ without preservatives. The $\mathrm{pH}$ and conductivity were measured on unfiltered samples in an on-site laboratory. The precipitation samples went to National Central University for chemical analysis and streamwater samples went to Taiwan Endemic Species Research Institute in Nantou for chemical analysis. Samples were stored at $4{ }^{\circ} \mathrm{C}$ prior to analysis. Filtered samples (Gelman Science GN-6 grid $0.45 \mu \mathrm{m}$ sterilized filter paper) were analysed for major anions and cations using Dionex 4000 ion chromatographs (Dionex Crop., Sunnyvale, CA) following King and Yang (1984) and Wang et al. (1998).

Ion concentrations were multiplied by the quantity of rainfall and streamflow to calculate ion fluxes on a weekly basis. The weekly sampling did not allow us to directly characterise typhoon-induced precipitation and streamflow, as typhooninduced rainfall and streamflow typically lasted less than a week and thus some non-typhoon induced rainfall and stream water was included to varying degrees in the weekly samples. Three typhoons spanned two weekly samples and, the contribution of typhoon-induced nutrient input and output in each of the two weeks was calculated by multiplying the weekly concentration by the amount of typhoon-induced precipitation/streamflow falling in the respective week. The contributions in both weeks were added together to give the total contribution of the typhoon.

For the few months when samples were not acquired due to logistical problems, monthly mean concentration values were used from the same month in the other years for which there were data. This monthly average approach was used to generate $<3 \%$ of rainfall and $<7 \%$ of streamflow data over the six years of the study. The two streamwater samples with $\mathrm{NH}_{4}+$ concentrations more than an order of magnitude higher than all other samples were considered contaminated and not included in the analysis. These two streamwater sam- ples represented $<1 \%$ of the annual streamflow and thus their exclusion had no discernable influence on the quantity or patterns of $\mathrm{NH}_{4}{ }^{+}$output.

Weekly rainfall varied from 0 to $820 \mathrm{~mm}$ and both extremes occurred in 2008-2009 for which there was uninterrupted streamflow data. Using 2008-2009 data we determined the relationship between weekly precipitation and weekly stream discharge $\left(Y=9.91+0.33 X+5.00 X^{2}+\right.$ $0.20 X^{3}-0.36 \times 10^{-4} X^{4}+1.6 \times 10^{-7} X^{5},[\mathrm{~mm}], R^{2}=0.93$, $p<0.0001$ ). During 2008-2009 weekly discharge ranged from $0.01 \mathrm{~mm}$ to $400 \mathrm{~mm}$, encompassing the full range of observations during the six years of the study 2005-2010. Based on the strength of this relationship we used weekly precipitation to calculate weekly stream discharge when direct discharge measurements were not available.

\section{Results}

The number of typhoons observed per year ranged from one in 2009 and 2010 to four in 2008 with a six-year average of 2.3 typhoons $\mathrm{yr}^{-1}$ (Table 1). Twelve typhoons occurred between mid-July and mid-September of the six-year period, one in late September and one in early October.

\subsection{Typhoon rainfall and streamflow characteristics}

The 14 typhoon storms brought $5370 \mathrm{~mm}$ precipitation or $1 / 3$ of the total rainfall over the six years during an aver-

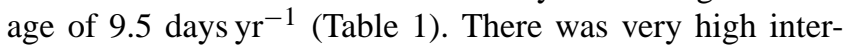
annual variation in typhoon-induced rainfall in terms of absolute quantity (Fig. 2) and the proportion of the annual rainfall during typhoons with $4 \%(76 \mathrm{~mm})$ in 2010 and $55 \%$ $(2140 \mathrm{~mm})$ in 2008 . The intensity of both the rain and wind of the typhoons observed also varied considerably (Table 1). The 2008 typhoon Sinlaku had $960 \mathrm{~mm}$ rainfall, with a daily maximum of $500 \mathrm{~mm} \mathrm{~d}^{-1}$, the highest of the 14 typhoons. Typhoon Kalmaegi (2008) had a maximum hourly rainfall of $96 \mathrm{~mm} \mathrm{~h}^{-1}$ the highest among the 14 typhoons and a total rainfall of $480 \mathrm{~mm}$. In contrast, the 2010 typhoon Fanapi had the second lowest hourly and lowest daily maximum rainfall rates, $13 \mathrm{~mm} \mathrm{~h}^{-1}$ and $28 \mathrm{~mm} \mathrm{~d}^{-1}$, respectively (Table 1).

The total typhoon storm runoff was $3300 \mathrm{~mm}$ or $31 \%$ of total streamflow during the six-year period. The mean annual runoff ratio was $0.60 \pm 0.03$ (mean \pm standard error) over the entire six-year period and did not differ between typhoon periods $(0.55 \pm 0.03)$ and non-typhoon periods $(0.63 \pm 0.07)$ (paired- $t$ test, $t=-1.69, p=0.15$ ). Inter-annual variation in the contribution of typhoon-induced runoff was comparable to the variation in typhoon-induced rainfall ranging from $3.1 \%$ (2010) to $58 \%$ (2008). In three of the six years the highest monthly rainfall and in four of the six years the highest monthly streamflow was associated with typhoons (Fig. 2). In September 2008, the highest monthly rainfall $(1520 \mathrm{~mm})$ and streamflow $(930 \mathrm{~mm})$ were observed during 
Table 1. Wind velocity $\left(\mathrm{m} \mathrm{s}^{-1}\right)$ at the typhoon centre, and rainfall $(\mathrm{mm})$ and stream flow $(\mathrm{mm})$ of typhoons between 2005 and 2010 at Lienhuachi Experimental Forest.

\begin{tabular}{|c|c|c|c|c|c|c|c|}
\hline \multirow{2}{*}{ Year } & \multirow{2}{*}{ date } & \multirow{2}{*}{ Names } & \multirow{2}{*}{$\begin{array}{r}\text { Max. } \\
\text { wind } \\
\text { velocity }\end{array}$} & \multirow{2}{*}{$\begin{array}{r}\text { Total } \\
\text { rainfall }\end{array}$} & \multicolumn{2}{|c|}{ Max. rainfall intensity } & \multirow{2}{*}{$\begin{array}{r}\text { Total } \\
\text { Stream } \\
\text { flow }\end{array}$} \\
\hline & & & & & $\mathrm{mm} \mathrm{d}^{-1}$ & $\mathrm{~mm} \mathrm{~h}^{-1}$ & \\
\hline \multirow[t]{3}{*}{2005} & 16-20 July & Haitang & 55 & 475 & 300 & 26 & 270 \\
\hline & 3-6 August & Matsa & 40 & 500 & 350 & 34 & 290 \\
\hline & 30 August-1 September & Talim & 53 & 140 & 110 & 32 & 70 \\
\hline \multirow[t]{2}{*}{2006} & 12-15 July & Bilis & 25 & 440 & 240 & 27 & 260 \\
\hline & 14-16 September & Shanshan & 48 & 92 & 35 & 22 & 60 \\
\hline \multirow[t]{3}{*}{2007} & 16-19 August & Sepat & 53 & 170 & 82 & 12 & 90 \\
\hline & 17-19 September & Wipha & 48 & 230 & 170 & 18 & 140 \\
\hline & 4-7 October & Krosa & 51 & 300 & 160 & 44 & 180 \\
\hline \multirow[t]{4}{*}{2008} & 16-18 July & Kalmaegi & 33 & 480 & 450 & 96 & 270 \\
\hline & 26-29 July & Fungwong & 43 & 220 & 200 & 39 & 180 \\
\hline & 11-16 September & Sinlaku & 51 & 960 & 500 & 85 & 590 \\
\hline & 26-29 September & Jangmi & 53 & 480 & 380 & 41 & 270 \\
\hline 2009 & 5-10 August & Morakot & 40 & 800 & 440 & 49 & 540 \\
\hline 2010 & 17-20 September & Fanapi & 45 & 76 & 28 & 13 & 50 \\
\hline
\end{tabular}

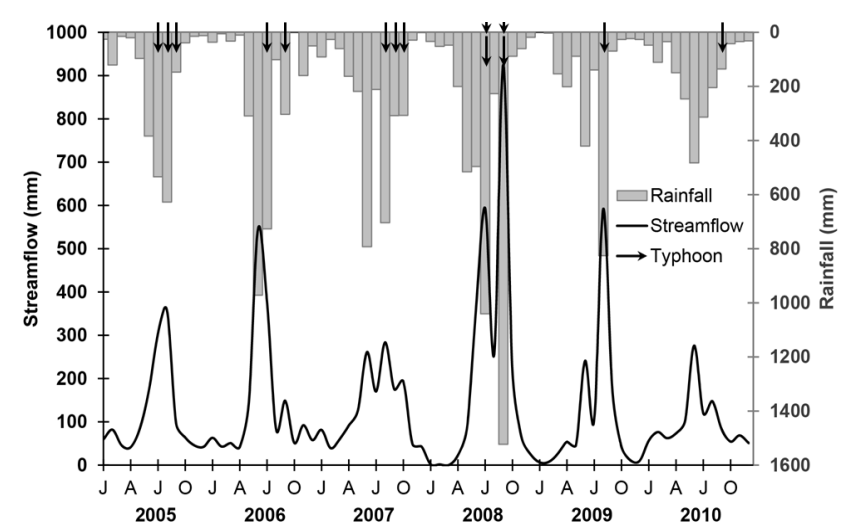

Fig. 2. The monthly rainfall and streamflow between 2005 and 2010. Each arrow indicates the occurrence of a typhoon.

the $6 \mathrm{yr}$ record, with $1440 \mathrm{~mm}$ of the rainfall and $860 \mathrm{~mm}$ of the streamflow contributed by two typhoons.

Maximum wind velocity of the 14 typhoons was not significantly correlated with the three key precipitation parameters: total rainfall, maximum hourly rainfall and maximum daily rainfall ( $r=-0.17$ to $-0.24, p=0.42-0.57)$.

\subsection{Typhoon influence on streamwater chemistry}

There was a clear wet-dry season variation in ion concentrations in streamwater (Fig. 3). Most ions $\left(\mathrm{Na}^{+}, \mathrm{Ca}^{2+}, \mathrm{Mg}^{2+}\right.$, $\mathrm{Cl}^{-}, \mathrm{SO}_{4}{ }^{2-}$ ) had significantly higher concentrations in the dry season than the wet season $(F=3.02-23.3$, all $p$ values $<0.05)$ whereas $\mathrm{NO}_{3}{ }^{-}$had higher concentrations in the wet season $(F=36.7, p<0.001)$. The differences in wet and dry season ion concentrations resulted, in part, from differences in flow rate. The weekly concentrations of $\mathrm{Na}^{+}, \mathrm{Ca}^{2+}$, $\mathrm{Mg}^{2+}$ and $\mathrm{SO}_{4}{ }^{2-}$ but not $\mathrm{NO}_{3}{ }^{-}$were significantly and negatively correlated with flow rate (logarithm regression models, $R^{2}=0.04-0.20$, all $p$ values $\left.<0.01\right)$. The concentration of $\mathrm{NO}_{3}{ }^{-}$was significantly and positively correlated with flow rate (logarithm regression models, $R^{2}=0.10, p<0.01$ ).

Typhoon induced fluctuations of ion concentration in stream water were barely observable on a monthly scale (Fig. 3). At a weekly scale typhoons resulted in very high flows for short periods of time and caused major, but shortlived, changes in stream water ion concentrations (Fig. 4). Ion concentrations varied considerably among typhoons. Except for $\mathrm{NO}_{3}{ }^{-}$, the concentrations of all analysed ions decreased dramatically in streamwater during weeks affected by typhoon, but returned to pre-typhoon levels within one to a few weeks (Fig. 4), indicating very high resilience of streamwater chemistry to typhoon disturbance in the subtropics. The concentration of $\mathrm{NO}_{3}{ }^{-}$increased considerably during typhoon-affected weeks, but also returned to pre-typhoon levels in one to a few weeks (Fig. 4). The greatest ion fluctuations during the six-year study were during non-typhoon periods (Fig. 3). 

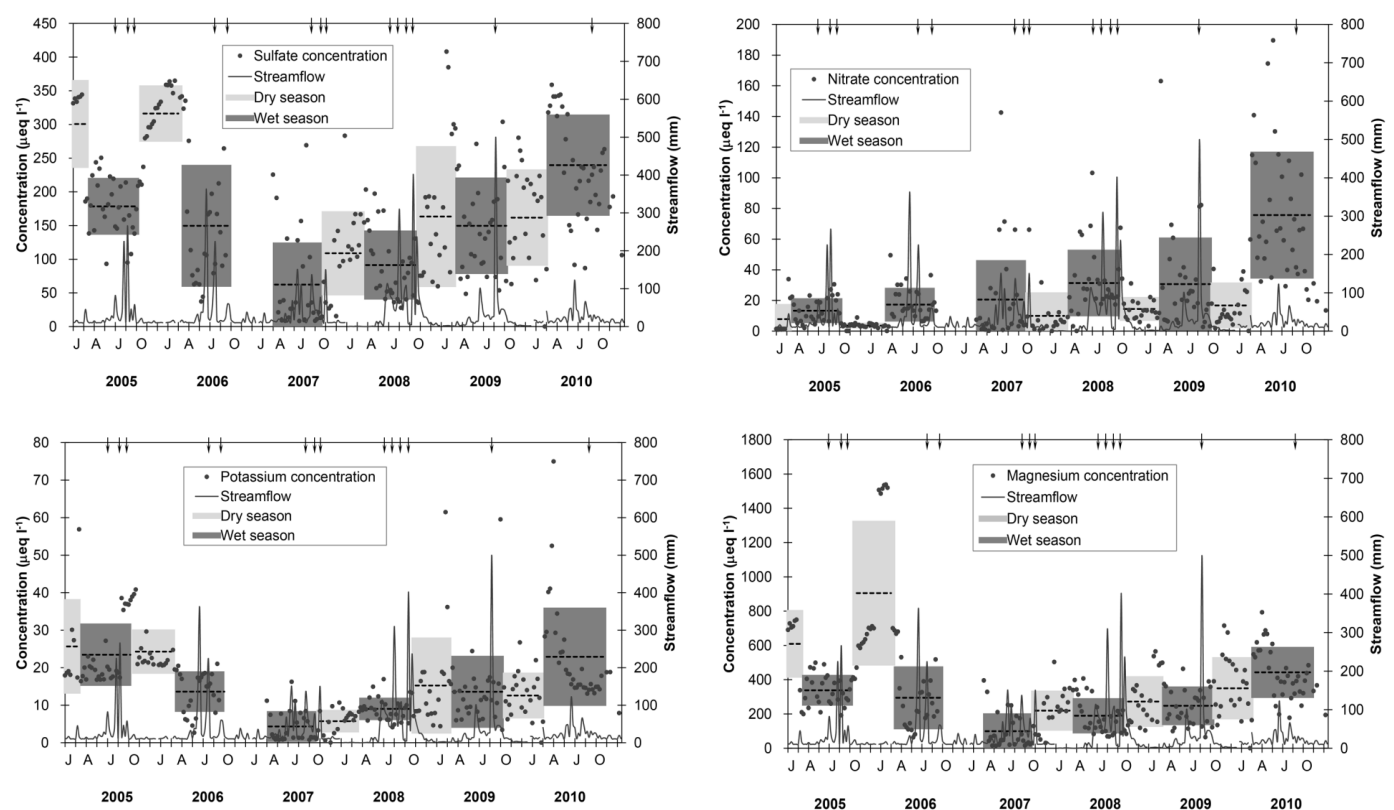

Fig. 3. Weekly streamwater chemistry between 2005 and 2010. Each arrow indicates a typhoon. Dash lines and gray rectangles represent the mean and one standard deviation of ion concentration during dry (October-February) and wet (March-September) seasons.
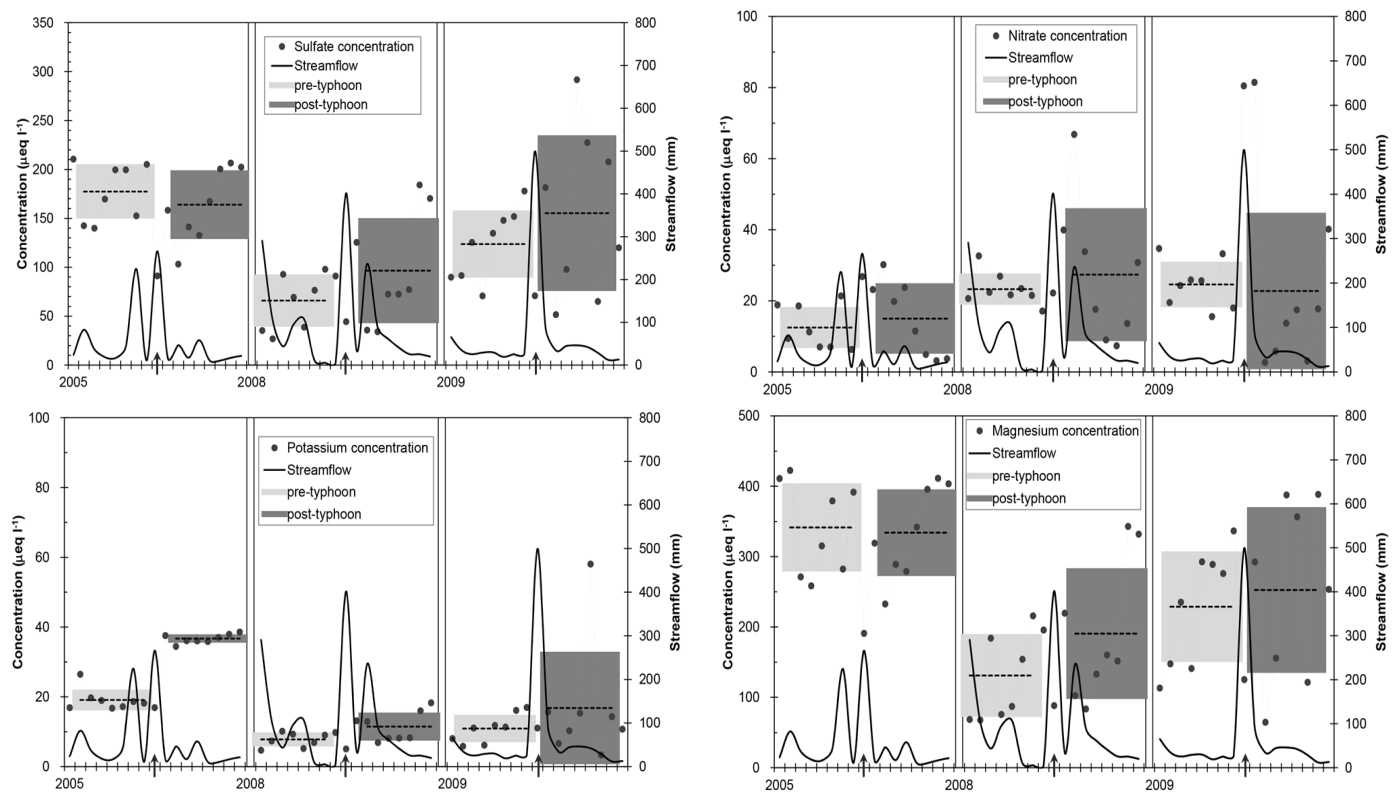

Fig. 4. Weekly streamflow and mean streamwater chemistry of the 8 weeks before and 8 weeks after the three typhoons with the highest amount of rainfall between 2005 and 2010 (Matsa in 2005, Sinlaku in 2008 and Morakot in 2009). Each arrow indicates the week of typhoon occurrence. Dash lines and gray rectangles represent the mean and one standard deviation of ion concentration of the 8 weeks before and after typhoons.

\subsection{Contribution to nutrient balances}

Mean proportional contribution of typhoon storms to hydrological and ionic inputs was not statistically different (paired- $t$ tests, all $p$ values $>0.10$, Table 2) except for $\mathrm{NH}_{4}{ }^{+}$ and $\mathrm{NO}_{3}{ }^{-}$, which are dominated by anthropogenic inputs.
The input of $\mathrm{NO}_{3}{ }^{-}$and $\mathrm{NH}_{4}{ }^{+}$via typhoon-related rainfall was proportionally less than non-typhoon precipitation ( $18 \%$ for both, paired- $t$ test $p=0.08$ for $\mathrm{NH}_{4}{ }^{+}$and $p=0.01$ for $\mathrm{NO}_{3}{ }^{-}$) suggesting that typhoon air masses are relatively "clean" with respect to anthropogenic inputs. The dilution effect caused by the "clean" air masses is evident from the 
Table 2. Mean annual water $(\mathrm{mm})$ and nutrient $\left(\mathrm{kg} \mathrm{ha}^{-1}\right)$ input through rainfall and output through streamwater at Lienhuachi Experimental Forest in central Taiwan between 2005 and 2010. Numbers in parenthesis are standard errors.

\begin{tabular}{|c|c|c|c|c|c|c|c|c|c|c|}
\hline & $\mathrm{H}_{2} \mathrm{O}$ & $\mathrm{H}^{+}$ & $\mathrm{Na}^{+}$ & $\mathrm{K}^{+}$ & $\mathrm{Mg}^{2+}$ & $\mathrm{Ca}^{2+}$ & $\mathrm{NH}_{4}^{+}$ & $\mathrm{Cl}^{-}$ & $\mathrm{NO}_{3}{ }^{-}$ & $\mathrm{SO}_{4}{ }^{2-}$ \\
\hline \multicolumn{11}{|l|}{ Rainfall } \\
\hline Total & $2600(380)$ & $0.21(0.044)$ & $3.5(0.64)$ & $2.2(0.29)$ & $0.47(0.06)$ & $3.7(1.03)$ & $12(1.8)$ & $5.7(0.37)$ & $27(2.2)$ & $27(3.8)$ \\
\hline Typhoon & & & & & & & & & & \\
\hline quantity & $890(290)$ & $0.081(0.028)$ & $1.1(0.26)$ & $0.81(0.32)$ & $0.15(0.04)$ & $0.83(0.28)$ & $2.1(0.59)$ & $2.0(0.51)$ & $4.9(1.4)$ & $8.3(3.4)$ \\
\hline$\%$ & $34(8)$ & $39(8.5)$ & $31(5.5)$ & $37(9.7)$ & $32(6.9)$ & $22(7.0)$ & $18(6.3)$ & $35(6.8)$ & $18(4.5)$ & $31(7.4)$ \\
\hline \multicolumn{11}{|l|}{ Streamflow } \\
\hline Total & $1570(140)$ & $0.05(0.02)$ & $24(6.2)$ & $6.3(1.6)$ & $33(7.6)$ & $59(14.7)$ & $0.23(0.03)$ & $16(2.5)$ & $36(6.7)$ & $66(9.3)$ \\
\hline Typhoon & & & & & & & & & & \\
\hline $\begin{array}{l}\text { quantity } \\
\%\end{array}$ & $\begin{array}{r}490(180) \\
31(8.2)\end{array}$ & $\begin{array}{r}0.013(0.006) \\
26(8.2)\end{array}$ & $\begin{array}{r}7.4(2.8) \\
31(6.9)\end{array}$ & $\begin{array}{r}2.0(0.81) \\
32(6.5)\end{array}$ & $\begin{array}{r}8.8(3.0) \\
27(5.9)\end{array}$ & $\begin{array}{l}12(4.7) \\
20(5.6)\end{array}$ & $\begin{array}{r}0.083(0.023) \\
37(9.1)\end{array}$ & $\begin{array}{r}4.9(1.2) \\
31(7.2)\end{array}$ & $\begin{array}{l}15(4.5) \\
42(11)\end{array}$ & $\begin{array}{l}17(4.1) \\
26(7.7)\end{array}$ \\
\hline \multicolumn{11}{|c|}{ Output: input ratio } \\
\hline Typhoon & $0.55(0.031)$ & $0.16(0.11)$ & $6.7(1.7)$ & $2.5(0.76)$ & $59(11)$ & $14(5.6)$ & $0.039(0.018)$ & $2.5(0.51)$ & $3.1(0.70)$ & $2.1(0.82)$ \\
\hline Non-typhoon & $0.63(0.068)$ & $0.29(0.15)$ & $6.9(2.0)$ & $3.1(1.5)$ & $76(42)$ & $16(8.8)$ & $0.015(0.0071)$ & $3.0(0.52)$ & $0.95(0.20)$ & $2.6(0.62)$ \\
\hline
\end{tabular}

tight negative relationship between the quantity of typhoon rainfall and concentrations of $\mathrm{NO}_{3}{ }^{-}\left(R^{2}=0.55, p<0.001\right.$; Fig. 5a) and $\mathrm{NH}_{4}{ }^{+}\left(R^{2}=0.47, p<0.001\right.$; Fig. 5b). Proportional contribution of typhoons to the annual stream discharge $(31 \%)$ relative to ion output was not different (26$37 \%$, paired- $t$ tests, $p$ values $>0.10$, Table 2) except for $\mathrm{NO}_{3}{ }^{-}, \mathrm{H}^{+}$, and $\mathrm{Ca}^{2+}$. Not surprisingly proportionally more $\mathrm{NO}_{3}{ }^{-}(42 \%)$, and less $\mathrm{H}^{+}(26 \%)$ and $\mathrm{Ca}^{2+}(20 \%)$ were exported during typhoon periods (one-tail paired-t test both $p$ values $<0.01$, Table 2 ).

Differences in the output: input ratio between typhoon and non-typhoon periods can be used to evaluate typhoon impacts on ecosystem level retention/export of nutrients. The mean annual output: input ratio did not differ between typhoon and non-typhoon periods for all ions examined (paired-t test $p$ values $>0.15$ ) except for $\mathrm{NO}_{3}{ }^{-}$, indicating that typhoons did not change the ion export pattern. For $\mathrm{NO}_{3}{ }^{-}$, the output: input ratio was consistently and significantly greater during typhoon periods than nontyphoon periods (Fig. 6; one tail paired- $t$ test, $p=0.035$ ). The mean annual output: input ratio of $\mathrm{NO}_{3}{ }^{-}$during nontyphoon period was 0.95 and was not significantly different from one (one sample $t$-test $t=-0.23, p=0.83$ ). However, during typhoons the output: input ratio was consistently and considerably greater than 1 (one sample $t$ test $t=4.24, p=0.008$; Fig. 6) with a mean ratio of 3.1 (Table 2). Notably the mean typhoon-induced annual $\mathrm{NO}_{3}{ }^{-}$ loss (output - input) of $10 \mathrm{~kg} \mathrm{ha}^{-1}$ (Table 2) occurred during the average 9.5 days when typhoons influenced the study site (Table 1). Over the six-year study period a total of $62 \mathrm{~kg} \mathrm{ha}^{-1} \mathrm{NO}_{3}{ }^{-}$was lost during 57 typhoon days, resulting in a loss of approximately $31 \mathrm{~kg} \mathrm{NO}_{3}^{-} \mathrm{ha}^{-1} \mathrm{mo}^{-1}$ or $1 \mathrm{kgha}^{-1} \mathrm{~d}^{-1}$ during the typhoon period. The amount of $\mathrm{NO}_{3}{ }^{-}$output during the typhoon period can be predicted by streamflow $\left(R^{2}=0.64, p<0.001\right.$; Fig. $\left.5 \mathrm{c}\right)$ suggesting that leaching largely determines $\mathrm{NO}_{3}{ }^{-}$loses.

\section{Discussion}

\subsection{The need for rainfall to be included in the cyclone impact forecasting system}

The lack of a significant correlation between wind velocity and rainfall associated with typhoons indicates that the Saffir-Simpson wind-velocity based classification system is not very useful for predicting the influence of tropical cyclones on ecosystem hydrochemistry. Because the flooding associated with tropical cyclones often causes more property and ecosystem damage than do high winds (Trousdell et al., 1965; Cremer et al., 1977; Foster, 1988; Atallah and Bosart, 2003; Lin, C. W. et al., 2011; Tsou et al., 2011; West et al., 2011), a storm rating system that includes rainfall would be far more useful in preparing for, and understanding, the impacts of tropical cyclones on human and natural systems.

\subsection{Variation in typhoon-induced rainfall and streamflow}

In the absence of typhoons, mean annual precipitation and stream runoff would be about 1/3 less in central Taiwan. Because the typhoon season in central and southern Taiwan is followed by a dry period, typhoons most likely mitigate drought stress, as the soil is fully saturated at the beginning of the dry season. This effect is of great ecological importance because the dry period is followed by early spring when new leaf growth occurs as well as increasing evapotranspiration. A soil water deficit at this crucial time would negatively impact plant growth. However, the annual contribution of typhoons to rainfall and stream runoff is highly variable $(<5 \%$ to $>50 \%)$ and stochastic. The inter-annual variability in typhoon-caused groundwater recharge highlights the importance of developing water resource management plans that take this stochasticity in cyclone-induced rainfall into consideration. Increases in climate extremes, including shifts 
(a)

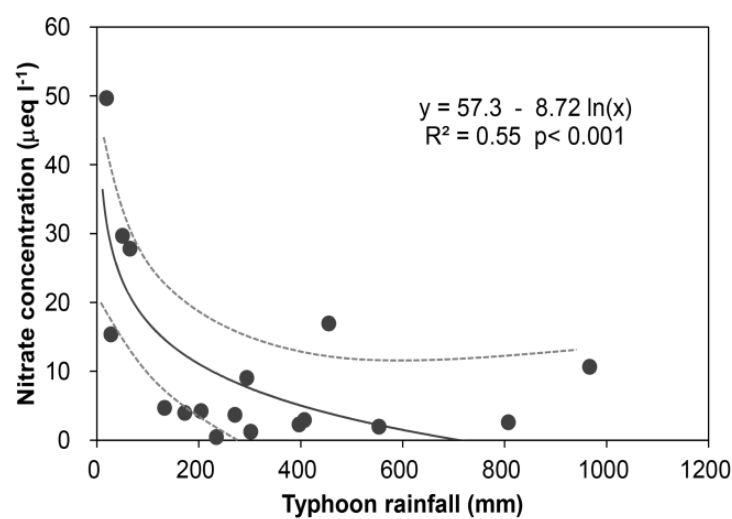

(b)

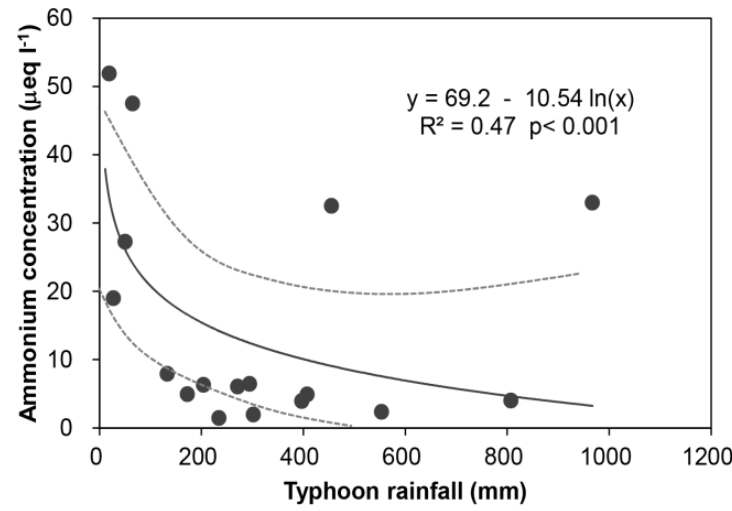

(c)

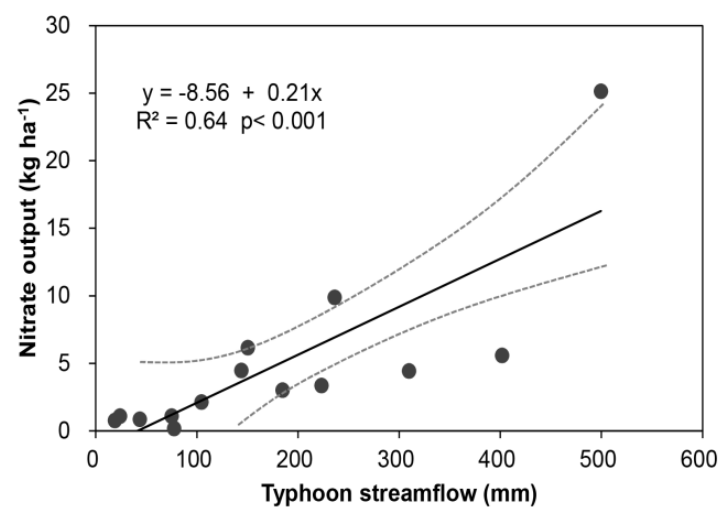

Fig. 5. The relationships between concentration and water quantity of $\mathrm{NO}_{3}{ }^{-}$and $\mathrm{NH}_{4}{ }^{+}$in typhoon rainfall (a) and (b) and between $\mathrm{NO}_{3}{ }^{-}$output and typhoon streamflow (c).

in tropical cyclone intensity as suggested by several studies (Webster et al., 2005; Knuston et al., 2010), can realistically be expected to increase variability in cyclone-induced rainfall, making water resource management ever more challenging and important.

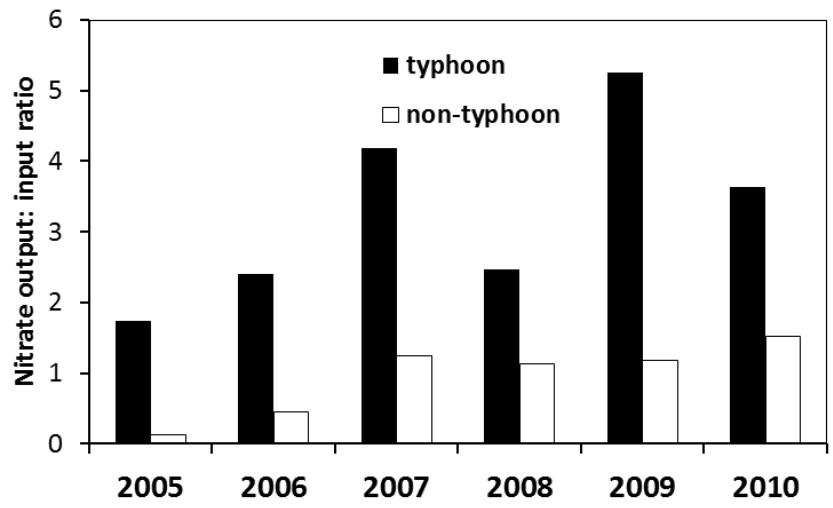

Fig. 6. The output: input ratio of $\mathrm{NO}_{3}{ }^{-}$during typhoon- and nontyphoon periods between 2005 and 2010 .

\subsection{Nutrient cycling during typhoon and non-typhoon periods are quantitatively and qualitatively different}

The similar proportional contribution of typhoons to the input and output of water and most ions suggests that the influence of typhoons on nutrient input and output could be accurately estimated by the amount of water they contribute. However, the flux of water and ions are very different between typhoon and non-typhoon periods, with typhoons contributing approximately $30 \%$ of water and most ions to the larger landscape over a roughly two month period. On average the flux rates of water and most ions into and out of the watershed were an order of magnitude greater during the two-month typhoon period than the non-typhoon period.

Unlike other ions, patterns of $\mathrm{NO}_{3}{ }^{-}$input and output were different between typhoon and non-typhoon periods. The forest was a nitrate balanced system during non-typhoon period, but lost a large amount of nitrate during typhoon periods. Because nitrogen is a macro-nutrient with very high biological demand the net loss (output - input) of, on average, $10 \mathrm{~kg} \mathrm{NO}_{3}{ }^{-} \mathrm{ha}^{-1} \mathrm{yr}^{-1}$ during the typhoon period $\left(9.5 \mathrm{~d} \mathrm{yr}^{-1}\right)$ could be important, as it accounts for more than $1 / 4$ of the annual $\mathrm{NO}_{3}{ }^{-}$output $\left(36 \mathrm{~kg} \mathrm{ha}^{-1}\right)$ occurring at an average rate of $1 \mathrm{~kg} \mathrm{NO}_{3}{ }^{-} \mathrm{ha}^{-1} \mathrm{~d}^{-1}$. Some of the $\mathrm{NO}_{3}{ }^{-}$lost was directly from precipitation but not all. Although frequent typhoon disturbance with high rainfall is characteristic of our study site, high concentrations of nitrogen in atmospheric input did not occur until the late 20th century, when Taiwan began to experience rapid industrialization. Prior to industrialization, $\mathrm{NO}_{3}{ }^{-}$deposition via precipitation in Lienhuachi was likely to be $<7 \mathrm{~kg} \mathrm{ha}^{-1} \mathrm{yr}^{-1}$ which is the current deposition rate measured in high elevation forests in central Taiwan, areas largely uninfluenced by local industrial activities (Ding et al., 2011). The $\mathrm{NO}_{3}{ }^{-}$loss resulting from soil and foliar leaching during typhoon periods might be enhanced as a result of recent anthropogenic activities, which could lead to higher foliar and soil N content (Pitcairn et al., 1998; 
Lovett and Rueth, 1999), and could have adverse effects on down stream ecosystems and water uses. Nitrogen pulses following fertilization and snowmelt have been shown to negatively affect water quality of municipal wells and groundwater (Exner et al., 1991; Ohte et al., 2004). Although we did not analyse $\mathrm{PO}_{4}{ }^{3-}$ concentrations, a study in northeastern Taiwan indicates that more than $20 \%$ of dissolved phosphorus and $60 \%$ of particulate phosphorus output in streamwater occurred during typhoon periods (Wang et al., 2001). Such typhoon-induced pulses of the most common limiting nutrients (i.e. $\mathrm{N}$ and $\mathrm{P}$ ) are likely to affect down stream and coastal primary productivity, but to our knowledge these effects have not been examined.

Increased stream water concentrations of $\mathrm{NO}_{3}{ }^{-}$during high flow are typically attributed to enhanced leaching from foliage and litterfall (Fenn et al., 1998; Balestrini et al., 2006). Although typhoons do not cause high tree mortality in Taiwan, defoliation is common (Lin, T. C. et al., 2011). In northeastern Taiwan canopy leaf area index dropped as much as 2/3 following six typhoons in 1994 (Lin, T. C. et al., 2011 ) and in the current study site it dropped $20 \%$ following typhoon Haitang in 2005 (Chen et al., 2007). Because typhoons are unpredictable there is likely little retranslocation before the leaves fall as a result of high winds. Thus, leaching from these relatively nutrient-rich leaflitter could be substantial and lead to high levels of $\mathrm{NO}_{3}{ }^{-}$export during typhoons. This implies that typhoon disturbances create a more open (leaky) ecosystem. It is important to evaluate how climate induced changes in tropical cyclone frequency and intensity (Webster et al., 2005; Knuston et al., 2010), might affect ecosystem biogeochemistry.

\subsection{Ecosystem resilience and resistance}

The dramatic fluctuation in ion concentrations before and after typhoons indicates that typhoons impact streamwater chemistry, but the fluctuations are short-lived, lasting a few weeks at most. Despite what might be predicted from observations in the western hemisphere, streamwater chemistry at the Lienhuachi Experimental Forest is highly resilient to typhoon disturbance. Although fluctuations were dramatic, they were no greater than the fluctuations observed during non-typhoon periods. Given that annual peak flows occur during typhoons (four out of the six years observed), the lack of dramatic fluctuations during typhoon periods suggests that streamwater chemistry at Lienhuachi Experimental Forest is relatively resistant to typhoon disturbance.

Studies of typhoon disturbance at Fushan Experimental Forest of northeastern Taiwan suggest that structural resistance (low tree mortality) contributes to functional resilience (quick recovery of streamwater chemistry) and together they contribute to the maintenance the ecosystem stability (Lin, T. C. et al., 2011). Without high tree mortality the changes in streamwater chemistry are mostly associated with leaching caused by heavy rainfall with plant uptake of nutrients largely unaffected, allowing streamwater chemistry to recover quickly (Lin, T. C. et al., 2011). The results reported here suggest that streamwater chemistry exhibits both high resilience and high resistance with the former being evident at a weekly time scale and the latter at a seasonal or annual scale.

A study of typhoon-induced tree mortality at Lienhuachi Experimental Forest and Fushan Experimental Forest indicates that annual tree mortality is very low in both forests $(<1 \%)$ despite frequent typhoons (Forsyth, 2006). Very low tree mortality and minimal damage to forest understory plants means that the Lienhuachi Experimental Forest is capable of continuously taking up nutrients from soil solution. Therefore, once the heavy rains stop, leaching of nitrate and other nutrients from foliage and soils does as well, returning to stream water concentrations similar to those observed prior to the typhoon disturbance.

For regions experiencing high tropical cyclone frequencies such as Taiwan, high resistance and resilience are crucial for maintaining ecosystem structure and function. If the elevated concentration of $\mathrm{NO}_{3}{ }^{-}$lasted for more than a year as reported following hurricane Hugo at Luquillo Experimental Forest in Puerto Rico (McDowell, 2001), the ecosystem of Lienhuachi Experimental Forest as well as those in many parts of Taiwan would be nitrogen depauperate, which in turn negatively affects a wide range of ecosystem functions, such as net primary productivity.

Currently our understanding of tropical cycloneecosystem interactions largely comes from a few wellstudied cyclones in the Western Hemisphere. Little is known about the applicability of the findings gained from studies of these few tropical cyclones to other cyclone-ecosystem interactions. The high variation in streamwater chemistry response among typhoons supports the notion that there is not such thing as a typical tropical cyclone event that can be used to characterise tropical cyclone-ecosystem interactions. Thus, although studies on specific events provides useful insights into cyclone-ecosystem interactions, extrapolating the results to other regions/systems or even other cyclones in the same region requires a great deal of caution.

Regardless of the high resilience, frequent disturbance can still lead to losses of large amounts of nitrogen even when biological demand is high and development of nitrogen limitation (Vitousek et al., 2010). Maintaining fluctuations within a relatively limited range, as observed in the current study, helps to minimise nitrogen loss from the ecosystem and delay the development of nitrogen limitation.

\section{Conclusions}

1. Typhoon storms in central Taiwan contribute approximately $1 / 3$ of precipitation and stream runoff during an average year, though it varies from 4 to $58 \%$. Typhoons most likely ameliorate drought stress in early 
spring when water demand from both natural and agriculture ecosystems increases. Water resource management plans based on long-term typhoon precipitation averages will not meet their objectives given the highly variable frequency and characteristics of typhoons.

2. The quantity of rainfall associated with typhoons is not correlated with typhoon wind velocity. Because rainfall and the associated runoff often cause more damage to natural and human-built systems than do the associated high winds the current tropical cyclone classification/warning system does not accurately predict tropical cyclone damages.

3. Typhoons contributed approximately $30 \%$ of the input and output of most nutrients over an approximately two-month period to the forests of central Taiwan. On a monthly basis, nutrient input-output rates during typhoon periods were an order of magnitude greater than during non-typhoon periods.

4. Typhoon storms contributed $18 \%$ of the total $\mathrm{NO}_{3}{ }^{-}$ input, but about $40 \%$ of output. Approximately $10 \mathrm{~kg} \mathrm{ha}^{-1} \mathrm{yr}^{-1}$ of total $\mathrm{NO}_{3}{ }^{-}$loss occurred during the typhoon period, at an average rate of $1 \mathrm{~kg} \mathrm{ha}^{-1}$ $\mathrm{d}^{-1}$, leading to stream $\mathrm{NO}_{3}{ }^{-}$pulses that could be having adverse effects on downstream and coastal ecosystems.

5. Streamwater chemistry changes during typhoons but returns to pre-typhoon concentrations rapidly, indicating high resilience to typhoon disturbance. However, the magnitude of fluctuation in streamwater chemistry during typhoon periods is no greater than during nontyphoon periods, an indication of the high resistance of streamwater chemistry to typhoon disturbance. The high resilience and resistance of streamwater chemistry helps to minimise nutrient loss at Lienhuachi Experimental Forest despite experiencing frequent typhoons.

6. Typhoon-induced changes in streamwater chemistry varied considerably among events. Given this variation and the fact that our current understanding of tropical cyclone-ecosystem interactions is derived from studies of a limited number of tropical cyclones we need to remain open to our current understanding being potentially spurious.

Acknowledgements. We thank Jr.-Chuan Huang and Matthew Vadeboncoeur for insightful discussions and comments. We are grateful to the Lienhuachi Research Center of Taiwan Forestry Research Institute for logistical support. This research was supported in part by grants from the National Science Council of Taiwan (NSC100-2321-B-003-002)

Edited by: A. Butturini

\section{References}

Aber, J. D., Ollinger, S. V., Driscoll, C. T., Likens, G. E., Holmes, R. T., Freuder, R. J., and Goodale, C. L.: Inorganic nitrogen losses from a forested ecosystem in response to physical, chemical, biotic and climatic perturbations, Ecosystems, 5, 648-658, 2002.

Ancelin, P., Courbaud, B., and Fourcaud, T.: Development of an individual tree-based mechanical model to predict wind damage within forest stands, For. Ecol. Manage., 203, 101-121, 2004.

Atallah, E. H. and Bosart L. F.: The extratropical transition and precipitation distribution of hurricane Floyd (1999), Mon. Weather Rev., 231, 1063-1081, 2003.

Balestrini, R., Di Martino, N., and van Miegroet, H.: Nitrogen cycling and mass balance for a forested catchment in the Italian Alps, Assessment of nitrogen status, Biogeochemistry, 78, 97123, 2006

Beard, K. H., Vogt, A., Vogt, D. J., Scatena, F. N., Covich, A. P., Sigurdardottir, R., Siccama, T. G., and Crowl, T. A.: Structural and functional responses of a subtropical forest to 10 years of hurricanes and droughts, Ecol. Monogr., 73, 345-361, 2005.

Bell, G. D., Halpert, M. S., Schenll, R. C., Higgins, R. W., Lawrimore, J., Kousky, V. E., Tinker, R., Thiaw, W., Chelliah, M., and Artusa, A.: Climate assessment for 1999, B. Am. Meteorol. Soc., 81, S1-S50, 2000.

Beniston, M. and Diaz, H. F.: The 2003 heat weave as an example of summers in a greenhouse climate? Observations and climate model simulations for Basel, Switzerland, Global Planet. Change, 44, 73-81, 2004.

Chambers, J. Q., Fisher, J. I., Zeng, H., Chapman, E. L., Baker, D. B., and Hurtt, G. C.: Hurricane Katrina's carbon footprint on U.S. Gulf coast forests, Science, 318, p. 1107, 2007.

Chen, C. H., Lin, T. C., and Hwong, J. L.: Variations in the leaf area index and its effect on estimations of primary production in a natural hardwood forest and a Cunninghamia lanceolata plantation at the Lienhuachi Experimental Forest, central Taiwan, Taiwan J. For. Sci., 22, 423-439, 2007.

Christensen, J. H. and Christensen, O. B.: Climate modeling: severe summertime flooding in Europe, Nature, 421, 805-806, 2003.

Cook, G. D. and Goyens, C. M. A. C.: The impact of wind on trees in Australian tropical savannas: lessons from Cyclone Monica, Austral. Ecol., 33, 462-470, 2008.

Cremer, K. W., Myers, B. J., van der Duys, F., and Craig, I. E.: Silvicultural lessons from the 1974 windthrow in radiate pine plantations near Canberra, Austral. For., 40, 274-292, 1977.

Dail, A.: Drought under global warming: a review, WIREs Clim. Change, 2, 45-65, 2011.

Ding, S. B., Lin, T. C., Chan, S. C., Huang, J. L., and Lin, N. H.: Precipitation chemistry at a high elevation forest in central Taiwan, J. For. Res., 16, 438-445, 2011.

Everham III, E. M. and Brokaw, N. V. L.: Forest damage and recovery from catastrophic wind, Bot. Rev., 62, 113-185, 1996.

Exner, M. E., Burbach, M. E., Watts, D. G., Shearman, R. C., and Spalding, R. R.: Deep nitrate movement in the unsaturated zone of a simulated urban lawn, J. Environ. Qual., 20, 658-662, 1991.

Feller, M. C.: Trends in precipitation and streamwater chemistry in East Creek watershed in southwestern British Columbia, 19712008, J. Limnol., 69, 77-91, 2010.

Fenn, M., Poth, M. A., Aber, J. D., Baron, J. S., Bormann, B. T., Johnson, D. W., Lemly, A. D., McNulty, S. G., Ryan, D. E., and Stottlemyer, R.: Nitrogen excess in north American ecosystems: 
predisposing factors, ecosystem responses, and management strategies, Ecol. Appl., 8, 706-733, 1998.

Forsyth, E.: Patterns of typhoon damage in two subtropical forests, Sc.B. Thesis, Center for Environmental Studies, Brown University, Providence, RI, 2006.

Foster, D. R.: Species and stand response to catastrophic wind in central New England, USA, J. Ecol., 76, 135-151, 1988.

Foster, D. R., Aber, J. D., Melillo, J. M., Bowden, R. D., and Bazzaz, F. A.: Forest response to disturbance and anthropogenic stress, BioScience, 47, 437-445, 1997.

Gleason, S. M., Williams, L. J., Read, J., Metcalife, D. J., and Baker, P. J.: Cyclone effects on the structure and production of a tropical upland rainforest: implications for life-history tradeoffs, Ecosystems, 11, 1277-1290, 2008.

Heartsill-Scalley, T., Scatena, F. N., Estrada, C., McDowell, W. H., and Lugo, A. E.: Disturbance and long-term patterns of rainfall and throughfall nutrient fluxed in a subtropical wet forest in Puerto Rico, J. Hydrol., 333, 472-485, 2007.

Hornbeck, J. W., Bailey, S. W., Buso, D. C., and Shanley, J. B.: Streamwater chemistry and nutrient budgets for forested watersheds in New England: variability and management implications, For. Ecol. Manage., 93, 73-89, 1997.

Hsiao, H. M., Lin, T. C., Hwong, J. L., Huang, C. C., and Lin, N. H.: Precipitation chemistry at the Lienhuachi Experimental Forest in central Taiwan, Taiwan J. For. Sci., 22, 1-13, 2007.

Hwong, J. L., Liaw, S. C., Chen, M. C., King, H. B., and Lu, S. Y.: Review and analysis of forest hydrological researches in the Lienhuachi experimental forest, J. Exp. For. Natl. Taiwan Univ., 16, 95-114, 2002.

King, H. B. and Yang, B. Y.: Precipitation and stream water chemistry in PiluChi watersheds, Bull. Taiwan For. Res. Inst. Res. Rpt., 427, 1-42, 1984.

Knuston, T. R., McBride, J. L., Chan, J., Emanuel, K., Holland, G., Langsea, C., Held, I., Kossin, J. P., Srivastava, A. K., and Sugi, M.: Tropical cyclones and climate change, Nat. Geosci., 3, 157163,2010

Koh, G. C., Yang, B. Y., Lin, Y. L., Yang, C. C., and Chi, S. C.: A preliminary report of the forest watershed management research in Taiwan, Bull. Taiwan For. Res. Inst. Res. Rpt. 304, 1-50, 1978.

Liaw, S. C., Sheng, T. C., and Hwong, J. L.: A study of hydrologic responses of the Lienhuachi forest and clearcut site to Typhoon Norris, Taiwan J. For. Sc., 13, 237-241, 1998.

Likens, G. E. and Buso, D. C.: Variation in streamwater chemistry throughout the Hubbard Brook valley, Biogeochemistry, 78, 130, 2006.

Lin, C. W., Chang, W. S., Liu, S. H., Tsai, T. T., Lee, S. P., Tsang, Y. C., Shieh, C. L., and Tseng, C. M.: Landslides triggered by the 7 August 2009 Typhoon Morakot in southern Taiwan, Eng. Geol., 123, 3-12, 2011.

Lin, K. C., Hamburg, S. P., Tang, S. L., Hsia, Y. J., and Lin, T. C.: Typhoon effects on litterfall in a subtropical forest, Can. J. For. Res., 33, 2184-2192, 2003.

Lin, T. C., Hamburg, S. P., Lin, K. C., Wang, L. J., Chang, C. T., Hsia, Y. J., and Vadeboncoeur, M. A.: Typhoon disturbance and forest dynamics: lessons from a northwest Pacific subtropical forest, Ecosystems, 14, 127-143, 2011.

Lovett, G. M. and Rueth, H.: Soil nitrogen transformations in beech and maple stands along a nitrogen deposition gradient, Ecol. Appl., 9, 1330-1344, 1999.
Lu, S. Y., Tang, K. J., and Huang, H. H.: Climatic condition of forested lands of Taiwan forestry research institute, Taiwan J. For. Res., 15, 429-440, 2000.

McDowell, W. H.: Hurricanes, people, and riparian zones: controls on nutrient losses from forested Caribbean watershed, For. Ecol. Manage., 154, 443-451, 2001.

Moore, J. and Quine C. P.: A comparison of the relative risk of wind damage to planted forests in Border Forest Park, Great Britain, and the Central North Island, New Zealand, For. Ecol. Manage., 135, 345-353, 2000.

NWS (National Weather Service): Tropical cyclone definitions, National Weather Service Instruction 10-604, National Weather Service, NOAA, 2009.

Ohte, N., Sebestyen, S. D., Shanley, J. B., Doctor, D. H., Kendall, C., Wankel, S. D., and Boyer, E. W.: Tracing sources of nitrate in snowmelt runoff using a high-resolution isotopic technique, Geophys. Res. Lett., 31, L21506, doi:10.1029/2004GL020908, 2004.

Pitcairn, C. E. R., Leith, I. D., Sheppard, L. J., Sutton, M. A., Fowler, D., Munro, R. C., Tang, S., and Wilson, D.: The relationship between nitrogen deposition, species composition and foliar nitrogen concentrations in woodland flora in the vicinity of livestock farms, Environ. Pollut., 102, 41-48, 1998.

Powell, M. D. and Reinhold, T. A.: Tropical cyclone destructive potential by integrated kinetic energy, B. Am. Meteorol. Soc., 88, 513-526, 2007.

Scatena, F. N. and Larsen, M. C.: Physical aspects of Hurricane Hugo in Puerto Rico, Biotropica, 23, 317-323, 1991.

Schaefer, D. A., McDowell, W. H., Scatena, F. N., and Asbury, C. E.: Effects of hurricane disturbance on stream water concentrations and fluxes in eight tropical forest watersheds of the Luquillo Experimental Forest, Puerto Rico, J. Trop. Ecol., 16, 189-207, 2000.

Shiller, A. M., Shim, M. J., Guo, L. D., Bianchi, T. S., Smith, R. W., and Duan, S. W.: Hurricane Katrina impact on water quality in the East Pearl river, Mississippi, J. Hydrol., 414-415, 388-392, 2012.

Simpson, R. H. and Riehl, H.: The hurricane and its impact, Baton Rouge (Louisiana), Louisiana State University Press, 1981.

Trousdell, K. B., Williams, W. C., and Nelson, T. C.: Damage to recently thinned loblolly pine stands by Hurricane Donna, J. For., 63, 96-100, 1965.

Tsai, C. J., Lin, T. C., Hwong, J. L., Lin, N. H., Wang, C. P., and Hamburg, S. P.: Typhoon impacts on stream water chemistry in a plantation and an adjacent natural forest in central Taiwan, J. Hydrol., 378, 290-298, 2009.

Tsou, C. Y., Feng, Z. Y., and Chigira, M.: Catastrophic landslide induced by typhoon Morakot, Shiaolin, Taiwan, Geomorphology, 127, 166-178, 2011.

Vitousek, P. M., Porder, S., Houlton, B. Z., and Chadwick, O. A.: Terrestrial phosphorus limitation: mechanisms, implications, and nitrogen-phosphorus interactions, Ecol. Appl., 20, 5-15, 2010.

Wallace, J., Stewart, L., Hawdon, A., Keen, R., Karim, F., and Kemie, J.: Flood water quality and marine sediment and nutrient loads from the Tully and Murray catchments in the north Queensland, Australia, Mar. Freshwater Res., 60, 1123-1131, 2009.

Wang, L. J., Teng, T. C., Hsia, Y. J., King, H. B., and Liou, C. B.: Changes in streamwater chemistry of Fushan experimental 
forest during 1996 typhoon Gloria event, J. Exp. For. Natl. Taiwan Univ., 12, 189-201, 1998.

Wang, L. J., Teng, T. C., Hsia, Y. J., King, H. B., Liou, C. B., and Lin, T. C.: Changes streamwater chemistry of Fushan Experimental Forest during 1996 typhoon Herb event, Q. J. Chin. For., 32, 217-232, 1999.

Wang, L. J., Wu, C. C., Hsia, Y. J., and King, H. B. Phosphorus dynamics and output in the Fushan stream, NE Taiwan, Q. J. Chin. For., 34, 31-47, 2001.
Webster, P. J., Holland, G. J., Curry, J. A., and Chang, H. R.: Changes in tropical cyclone number, duration, and intensity in a warming environment, Science, 309, 1844-1846, 2005.

West, A. J., Lin, C. W., Lin, T. C., Hilton, R. G., Liu, S. H., Chang, C. T., Lin, K. C., Galy, A., Sparks, R. B., and Hovius, N.: Mobilization and transport coarse woody debris to the oceans triggered by an extreme tropical storm, Limnol. Oceanogr., 56, 77$85,2011$. 